\title{
Research-based Teacher Education for Multicultural Contexts
}

\author{
Judith K. Bernhard
}

Ryerson University

Carlos F. Diaz

Ryerson University

Ilene Allgood

Ryerson University

digital.library.ryerson.ca/object/361

Please Cite:

Bernhard, J. K., Diaz, C. F., \& Allgood, I. (2005). Research-based teacher education for multicultural contexts. Intercultural Education, 16(3), 263-277. doi:10.1080/14675980500211873

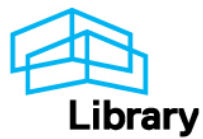




\title{
Research-based teacher education for multicultural contexts
}

\author{
Judith K. Bernhard*, Carlos F. Diaz and Ilene Allgood
}

Graduate programs in education face the challenge of preparing teachers and specialists in education to work with English Language Learners (ELLs). Programs must be culturally responsive, while at the same time respecting state and federal standards for scientifically based practice according to best evidence. The focus of the present study is a graduate program in education that sought to prepare graduate students to address the needs of ELL students. Among the articulated goals of the program grant were that teachers enrolled would be able to: (1) use effective English for Speakers of Other Languages and bilingual educational strategies and methods; (2) use findings from testing, assessment and research functionally; and (3) promote multilingualism, and, in a broader sense, respect and equitable treatment of the heritages of home languages. The extent to which graduates of the master's program who were working as teachers and administrators at the time of the study were able to make culturally competent connections with ELL students and to establish a repertoire of scientific evidence, based on research findings that they could then use to support their teaching theory and practice, is discussed. Findings reflecting the responses of 57 graduates of the program were as follows: (a) the training provided by the master's program was rated as more useful than the in-service provided by the state because its emphasis on research allowed graduates to judge the merits of proposed educational reforms and to clarify their own pedagogy; (b) the ability to cite research reports enabled graduates to be heard by colleagues and to depoliticize discussions regarding curricular reforms; (c) in developing their 'communities of practice', graduates made connections with others who had been trained in the use of scientific research in education. The study illustrates how a graduate education program focused on transformation and the encouragement of home language use can prepare teachers to work effectively in a political context of 'evidence-based practice'.

\section{Introduction}

The focus of the present study is a graduate program in education that sought to prepare graduate students to address the needs of ELL students. Among the articulated goals of the program grant were that teachers enrolled would be able to: (1) use

\footnotetext{
* Corresponding author. Judith Bernhard, School of Early Childhood Education, Ryerson University, 350 Victoria St, Toronto, ON M5B 2K3, Canada. EmaIl: bernhard@ryerson.ca
} 
effective English for Speakers of Other Languages and bilingual educational strategies and methods; (2) use findings from testing, assessment and research functionally; and (3) promote 'bilingualism', and, in a broader sense, equitable treatment of the heritages of first and second languages.

In most professions, practice according to a high standard is based on extensive education. Especially where sciences are concerned, that education-including updating or in-service training - must include intimate familiarity with up-to-date, solid research findings from rigorously conducted studies. Indeed, within public and social services generally, there have been official calls for and moves toward evidencebased practice. In the UK, David Blunkett, Secretary of State for Education and Employment, made the following statement:

Social science should be at the heart of policy-making. We need a revolution in relations between government and the social research community-we need social scientists to help to determine what works and why, and what types of policy initiatives are likely to be most effective. (cited in Evans \& Benefield, 2001, p.527).

Within the US, in the area of education, the federal government has started requiring reliance on scientifically based research. Within the No Child Left Behind Act (US Department of Education, 2001), scientifically based research has been defined quite precisely to mean rigorous empirical methods, experimental or quasi-experimental designs and replicability (Feuer et al., 2002).

In Canada, Australia, the UK, New Zealand and Sweden, there have been similar trends (see Davies \& Guppy, 1997; Weiner, 2002). The proponents of the new approach frequently argue by means of an analogy with the health sciences where the turn to scientific evidence has been part of the legitimizing of professional medical practice in the last century and where it is understood that scientific data are to be used in preference to anecdotal reports and centuries-old routines. The medical profession has become a 'community of practice' (Wenger, 1998).

Although there has been a great deal of debate over the education/health analogy, it will not be reviewed here (but see Davies, 1999; Evans \& Benefield, 2001; Hemsley-Brown \& Sharp, 2003; Horn, 2004). For the purposes of the present paper, it will be assumed that the scientific study of at least some features of the educational process and its outcomes can be carried out; indeed, such study has been carried out.

Faced with the demand for 'objective evidence' in education, educators, of course, have expressed great trepidation regarding the dangers of what has been called, the 'Era of Standards' (Tellez, 2003). Further, Cummins (2002) has noted that scientific approaches, as understood by state regulatory bodies, may be very narrowly focused and thus ignore such crucial variables as ELL students' cognitive engagement and identity investment. Nonetheless, this paper is based on the premise that teacher educators must prepare students for the challenges they face in conforming to statemandated standards, both for training according to research and for outcomes which, at least sometimes, must bear rigorous empirical assessment. At the same time, within language teaching, especially ESL, there are ethical as well as legislative demands for 'equitable treatment' of all groups. In particular, there is demand for respect for 
cultural and linguistic diversity. These requirements pose a number of dilemmas for professions. One common dilemma is that between raising the English performance level of certain 'ethnic' students and ensuring the preservation of their heritage and culture.

Florida, like a number of other locales, has looked toward the application of research findings to teaching and learning in its diverse cultural environment. Besides having to follow the regulations of the No Child Left Behind Act, Florida educators must face the mandates of their state government for the use of scientific evidence in assessing educational outcomes. In 1996, Florida implemented the Sunshine State Standards testing procedures/process, as measured by the Florida Comprehensive Assessment Test (FCAT). Results from these tests are used to identify critically low-performing schools. Both US federal and Florida state law require school systems to raise the achievement levels of students in each of five racial and ethnic subgroups every year. As well, the laws require that the achievement levels of students with limited English skills and those with disabilities be raised. Any deviation from steady improvement in any of these subgroups for two consecutive years results in a school being designated as 'low-performing'. If a school is seen as failing for two consecutive years, the school is required to facilitate student transfer to better schools and to provide private tutors for students. In the event that the school continues to be labeled 'low-performing', it must have its principal and teachers replaced or be re-opened as a charter school.

The problem of standards for language (including English) and ESOL teaching are exacerbated because teacher-training programs have increasingly been required to prepare professionals for practice with children of a rapidly diversifying population, one showing the results of an influx of bilingual and English as a second language students (González \& Darling-Hammond, 1997; Hermans, 2002; Lahdenpera, 2000; Nieto, 2003; Stoer \& Cortesao, 2001). At the same time, teacher education programs are being revised to bring them into compliance with state performance criteria (Ahlquist, 2003; Berlak, 2003; Gibson, 2003). Complying with such mandates is a particular challenge for programs that are focused on equitable equity goals regarding culture and race, for example, empowerment, transformation and respect for home languages.

Thus language teaching - including English, and ESOL - as a special area in education has had to pay more attention to research. Some of the debates over language and cultural preservation have become highly charged politically and, in this context, it is important for practitioners to be able to explain and justify their practices. Practitioners - and their administrators - need to be able to appeal to solid evidence as a basis for their approach. Whatever the limits of scientific research in education, it remains true that ways of teaching and learning which can survive the scrutiny of various interested stakeholders are best founded on rigorously derived and replicable evidence. We have in mind, in particular, the issue of the alleged benefits or harms of early acquisition of a second language.

A focus on research may also be viewed as a basis for establishing communities of practice. For instance Chang et al. (2003), in assessing a graduate program in 
education, looked at the general features of Wenger's (1998) 'communities of practice'. These features included mutual engagement and shared repertoire. The first feature focused on mutual relationships that were nourished among the diverse persons in the program. The second involved the establishment of a common knowledge base or repertoire. We would argue that the body of scientific research on multilingual and multicultural educational processes could serve as such a base.

Turning to the larger picture, over the last 30 years the number of foreign-born residents in the US has tripled, and this rate is expected to continue. Between 1990 and 2000, the population of English Language Learners (ELLs) among K-12 students in US schools doubled to almost 4.5 million. Yet minority language and minority dialect students (i.e. African-American vernacular or Ebonics speakers) are not succeeding in schools when compared with their counterparts. This lack of success can be measured by indicators such as overrepresentation in special education programs (Donovan \& Cross, 2002), high rates of suspension and expulsion (Polakow-Suransky, 2002), and dropout rates suggesting that almost half of these students drop out of school (Secada et al., 1998).

The present study was conducted in 2003 in Palm Beach County and Broward County, two adjoining school districts in south Florida, with teacher populations of nearly 13,000 and 15,000, respectively. Together, these two school districts serve over 500,000 students, a large majority of whom are Spanish-speaking. The second largest contingent is made up of Haitian-Creole speakers. Among the remainder, at least 30 other primary languages are spoken in the homes. Public schools in Palm Beach County report a total bilingual population of $16 \%$, reflecting nearly 27,000 students, and neighboring Broward County reports a 14\% ELL population, reflecting 38,065 of the county's 271,339 students in the 2003-2004 school year (Hoffman, 2003). Instruction in these two highly diverse school districts has been complicated by a dearth of qualified teachers and specialists in education with tangible skills and experience in ESOL, and in bilingual and multicultural education despite a decade-old mandate requiring English as a second language endorsement for permanent teaching certification.

In order to prevent a lawsuit for inadequate provision of education for linguistic minorities, in 1990, the State of Florida signed the Multicultural Education Training Advocacy (META) decree, which required school boards to submit annual status reports on steps taken to provide adequate education for ELLs. One of these requirements was an English as a second language endorsement coverage added to the teaching certificate which required 15 credit hours or 300 in-service points of mandated education components for all teachers, regardless of in-field or out-of-field status. Nonetheless, these professional development initiatives had limited success in becoming translated into practice in the field. In June 1999, the National Coalition of Advocates for Students (NCAS, an independent non-profit organization) and the Community Alliance for Reform in Education (CARE, another independent nonprofit organization) reported in a critical study ( $A$ Gathering Storm II) that Palm Beach County was still failing its poor and minority children. The research team of NCAS extensively examined the day-to-day operations of the school district, and the report alleged that school-disadvantaged, non-White and low socioeconomic status 
students were further being shortchanged in the system through tracking practices, disproportionately higher suspension rates, general exclusion and lower expectation levels. An imperative to prepare educators was underscored by the gaps and weaknesses in services, infrastructure, and/or opportunities for ELL students.

Proper research methods were not explicitly mentioned as the main objective of the master's program, but were emphasized and made a part of the core courses. 'Proper research methods' refers to methods being scientific, rigorous and replicable. The components of the training were designed to lead to State of Florida endorsement in English as a Second Language. The degree consisted of 12 courses, each lasting three semester hours, for a total of 36 semester hours. Core multicultural courses included: Foundations of Multicultural Curricula; Seminar in Multicultural Education; Race, Class and Gender in Education; and Teaching the African American Student. Core courses in the area of teaching English language learners were: Applied Linguistics and TESOL; Curriculum Development in TESOL; TESOL Teaching Methods; and Language Assessment Testing and Evaluation. In addition, students were exposed to critical knowledge of research in two research and statistics core courses. Some courses were not specifically designed to teach research, but they fully incorporated research in other ways (e.g. School Improvement). In this case, students had to carry out action research projects in their schools. Research findings were brought back to class and discussed with fellow graduate students. In addition, all the courses involved students by immersing them in research literature and in findings on relevant issues.

Besides the program graduates' knowledge and professional experience, the study focused on their conceptions of themselves now that they were all employed in the school system and working as a professional group and, moreover, as a community of practice. We looked at indicators of professional knowledge such as graduates' reports of improved understanding, their ability to articulate research findings, and their sense of support and ability to work in the system. The main questions addressed in the study were as follows:

1. To what extent do the graduates find their exposure to research useful in improving their understanding of appropriate practice with ESOL students?

2. How does the ability to articulate research findings contribute to graduates' ability to work with colleagues?

\section{Method}

\section{Participants}

The population of the study was the entire cadre of graduates from the two master's cohorts from the inception of the program from 1991 to 2000. In 2003, when our study was conducted, all graduates were employed as teachers or administrators in the Florida State school system. Attempts to contact 195 graduates resulted in 155 valid addresses. In addition, focus group sessions were conducted with a total of 16 graduates of the program, and individual interviews were conducted with seven graduates. (For a summary of participant demographics, see Appendix 1.) 
In order to gather direct evidence regarding the effectiveness of the graduates' knowledge and practice, we used interviews with two principals and four administrators who had direct contact with the graduates. To gather evidence from the families of ELL students, site visits were conducted and five parents of ELL students were interviewed on site at an elementary school.

\section{Apparatus}

A survey instrument was constructed by a team of professors from Florida Atlantic University and Canada's Ryerson University in Toronto. The survey was initially modeled after work conducted in New York (Advocates for Children, 2001). A preliminary pilot run was conducted with 14 degree-seeking students who were currently enrolled in the program. A restructured and clarified survey, containing a total of 106 items, including demographic questions geared toward the graduates, was piloted again. The instrument was then evaluated by its frequency output for its relative power and redundancy. Subsequently, the instrument was abbreviated into a tighter 36-item questionnaire and was mailed at the start of the 2003/2004 school year. The survey drew responses from 57 graduates, after being sent to the 155 valid addresses in file, yielding a response rate of $36.8 \%$.

Additional data were collected from three focus groups with graduates, five site visits and several interviews. The focus group questions that emerged from team meetings were as follows:

(a) What elements from your master's program have you found most useful in your work with English as a second language students and their families?

(b) What elements of your master's program have you drawn on to implement effective practice with regard to ELL students?

(c) What curricular changes or new elements would you suggest that would have made your master's program more effective?

(d) What barriers have you encountered in the schools you are currently working in and how have you coped with these barriers?

\section{Procedure}

In order to address the guiding question of the impact the master's program had made, data were generated through surveys, focus groups and interviews with the first two cohorts of graduates, and were collected over a one-year period. The survey was used to generate demographic data and evaluate responses about: (a) program aspects that were particularly valuable in working with the ELL population; (b) extent of implementation of program elements in the workplace; (c) assessment of school climate; and (d) work with families and communities.

Focus group sessions and individual interviews were conducted with graduates, administrators and parents to clarify and elaborate on survey responses; they were audio- and video-taped and transcribed. Site visits were conducted in order to 
triangulate the information gathered from the master's graduates and to obtain the views of other teachers and students. From these data, site visit reports were drafted.

\section{Results}

Finding 1: The training provided by the master's program was rated as more useful than the in-service ${ }^{1}$ provided by the state of Florida because its emphasis on research allowed graduates to judge the merits of proposed educational reforms and to clarify their own pedagogy

The overall majority of the graduates of the program reported that their practice was fundamentally improved because they had been in the program. Fifty-two out of 55 respondents said that the master's program was 'very useful or extremely useful' to their practice. Graduates were asked to rate the degree of usefulness of both the inservice courses and the master's level program. As is summarized in Table 1, graduates rated the program as being more useful than their in-service courses.

In elaborating on these ratings, graduates said they liked the focus on research of the master's program because it provided a foundation for their practice. For example, Evelyn, an experienced high school teacher, stated that the research literature brought into her graduate classroom by her professors and fellow students gave her a 'solid foundation'. Through examining research, she became acutely aware of the difficulties of current educational politics, and she recognized that any 'quick fix' to meet standards was impossible. One participant, Evelyn, talked about the knowledge she had gained from the program in advocating for ELL students and its links with research:

The legislators say these standardized tests are research-based. Yet we all know that acquiring thinking in a second language takes 5-9 years. Whose research are they looking at when testing children after a year and removing support within two years of arrival? There is nothing that is evidence-based about this.

Indeed the administrators and principals interviewed said that a strength of the graduates was that they had a solid foundation and were able to articulate the reasons behind their pedagogical preferences. Some graduates said they routinely undertook data collection efforts to help them improve their practice. Madelaine, for example, said:

Table 1. Perceived usefulness of in-service and master's program training

\begin{tabular}{lcc}
\hline & Master's program & In-service \\
\cline { 2 - 3 } Degree of usefulness & Per cent $(N)$ & Per cent $(N)$ \\
\hline Not at all useful/A little useful & $0(0)$ & $27(15)$ \\
Moderately useful & $5(3)$ & $38(21)$ \\
Very useful/Extremely useful & $94.5 \%(52)$ & $34.5(19)$ \\
Total & $100(N=55)$ & $100.0(55)$ \\
\hline
\end{tabular}


I felt at the beginning of the school year that there were little or no support or services for Limited English Proficient students and families. So along with a fellow teacher, we surveyed the families to see what services they would like. We have been conducting monthly meetings and attendance has soared. The last meeting had 78 parents. Now some of the parents have begun to volunteer in the school.

Finding 2: The ability to cite research reports enabled graduates to be heard by colleagues and to depoliticize discussions regarding curricular reforms

The teachers reported being under great pressure to implement the regulations which mandated sheltered instruction for ELLs. At the same time, they were instructed to do whatever was necessary to avoid their school being categorized as a 'low-performing' school by virtue of scores on the state's standardized tests. These contradictory demands resulted in heated discussions among colleagues that were often polarized according to political views. Graduates reported that their ability to cite research methods and findings was a powerful way to depoliticize the gap that existed between teachers and administrators. For example, Carla, a graduate who taught writing skills, cited Jim Cummins' writings on the length of time it takes to acquire academic proficiency in a second language (Cummins \& Fillmore, 2000) in response to proposed policy changes.

The administrators did not know what to do for the low-academic level students. I told them they couldn't expect students to write at the academic (Cognitive Academic Language, CALP) level before they have mastered the Basic Interpersonal Communicative Skills (BICS) social level. The course requirements were changed following Carla's presentation to the board.

Having access to research findings empowered the graduates to dialogue effectively with colleagues, regardless of their level of understanding of multicultural issues. As noted in Table 2, when asked to rate the statement, 'I am not afraid to speak my mind at meetings', most graduates (65\%) reported they were comfortable in speaking their minds at faculty meetings.

Further, as illustrated in Tables 3 and 4, over two-thirds of the respondents $(68.5 \%)$ said that the knowledge they had gained in the master's program had been solicited by their colleagues, and $66.6 \%$ said that they were supported by their administrators at their workplace.

In a focus group meeting, Lucy elaborated on how important it was for her to be able to cite research findings in order to have her views heard by colleagues:

Table 2. Extent to which graduates were not afraid to speak their minds at meetings

Categories

Per cent $(N)$

'Strongly disagree' \& 'Somewhat disagree'

$31.5(17)$

'Agree' \& 'Strongly agree'

'No opinion'

Total

$100.0(54)$ 
Table 3. Extent to which knowledge gained was solicited by colleagues

I can say that having a focus on research has done a lot for my work with ELL families and teachers and administrators who work with them. If I had not had access to the research I would not be able to back up my beliefs or to combat or speak against some things that are not true based on the research - things that people in the US believe that are not true.

As they joined their colleagues and administrators in meeting the demands of both the META decree and the Sunshine State Standards testing process, graduates found their ability to articulate research findings gave them a sense of authority and a feeling of confidence that their arguments would eventually be understood. One graduate who was a history teacher in a largely Hispanic school reported:

I saw that I could take the information that I was getting and feed it in small doses to people who wanted to hear it and to those who wanted to meet the needs of their students. The backing of the research stuff helped me for those people who did not want to hear it and I was able to go to a faculty meeting and state: Just read this if you can and check out the research on acquiring language at this level. Coming in literate about knowledge-based evidence, I felt I was able to lend significant insight.

Although graduates were generally satisfied with their ability to be heard by colleagues, they felt the need to learn more about the nature of legislative and funding decisions made by state and federal politicians. They also knew little about the situations of living without full status, a situation that was being experienced by many of the students and their families. This lack of awareness was observed during a science fair in a site visit of a school populated with migrant and undocumented Guatemalan families. The teachers asked these parents to participate in a fingerprinting activity as a way to encourage them to participate in their children's learning. On the one hand, fingerprinting may seem like an innocent activity but, on the other hand, it entails a profound political meaning that is equated with surveillance, especially for those living without legal status.

Table 4. Extent to which principal supported participant's curricular adaptations 
Finding 3. In developing their 'communities of practice', graduates made connections with others who had been trained in the use of scientific research in education

Most of the graduates felt strongly connected with others of the same program and cohort. This connection strengthened their practice and furthered their abilities to advocate for certain practices. The graduates jokingly referred to the local area teachers that had graduated from the program as 'the salmon', figuratively swimming upstream together against a tide of opposition against multicultural ideology. When program graduates met each other at school board meetings, they felt supported and encouraged to continue what they felt was like an uphill struggle to gain equity for ESOL students. Following is a comment from Norma who had graduated in 1998:

Our cohort is still very close, we still work very closely together in many ways. For instance, faculty at my school don't always look at their own as having expert knowledge. I've gotten some people from my cohort to come and speak because they don't know them and people are more willing to accept someone they don't know to come out and do some enlightening things.

Another graduate, Lucy, agreed:

As colleagues from the program, we network and have conversations that I wish I had when I started teaching 10 years ago. These relationships with people will support the research and help us advocate out loud for the students. I feel as if I am not the only fish in the sea. I communicate with other people who have been through the program. People that look for equity in education. It comes up in conversations-the issues of working with ESOL students. Teachers may ask how I learned something. I can advocate for the program or I may find out that they have been through the program.

Some graduates had developed communities of practice that went beyond the masters program graduates. For example, Joanne said,

I have had some influence in bringing in colleagues that are very up-and-coming in the research on reading and literacy. I have a principal who supports my views on using French as a second language since we have such a high Haitian-Creole population, and she's excited about it because she knows about the research.

\section{General discussion}

It is appropriate to look at the findings in terms of the broader goals already mentioned. There is good evidence that the graduates participating in our study had been forming 'communities of practice'. Several graduates specifically mentioned the closeness of the cohort, and the practice of asking one another to come and speak to their colleagues. Networking with others who were well-prepared to discuss issues in terms of scientific research was specifically mentioned as valuable.

In accord with the evidence-based approach to education, the graduates had become well-acquainted with scientific research in their areas of study. Further, they were able to use scientific research, cite it, and explain it in talking to colleagues and parents. There is evidence that the depoliticization of certain issues was to some extent accomplished. 
The question may be raised as to whether the teachers had over-simplified research findings or had attributed more validity to some particular finding than may be have been warranted. Further, although not reviewed here, it is valid to raise the question of their knowledge of the debate about scientific research in education in general and about, in particular, experienced educators whose experiential knowledge emphasizes contextual and pedagogical variables which are in themselves difficult to scientifically validate (On the importance of these factors, see Bransford et al., 1999). Nonetheless, the effects on outcomes have been reported in the literature (Bernhard et al., 2004).

It is possible that these graduates may have had too narrow a focus on scientific procedures at the expense of - equally valid, perhaps-qualitative approaches to understanding the lives of students and their families. One example that comes to mind is the discussion of recent literature in the role of cognitive engagement and identity investment in reading development and performance. So far as we can tell, these issues were not raised in the research literature to which the graduates were exposed. Would these graduates be inclined to see themselves as implementing scientific procedures at the expense of personal attunement to the interior lives of students and their families? No graduate mentioned such studies in discussing the research evidence on which she or he relied. The upshot of this discussion may be that training programs focusing on evidence would do well to look at that derived from a number of different but equally rigorous methods, including qualitative ones.

The data are subject to a number of limitations. The first limitation is that our report is limited to the responses of 57 people at one of dozens of universities in areas characterized by cultural and linguistic diversity in the US. It would be difficult to generalize the findings to other communities, states or countries, or to the teaching of ethnic groups other than those in the present context. A second limitation is the relative absence of direct evidence from the ELL students of the graduate teachers and the relative scarcity of direct evidence from families and administrators as to the efficacy of the new knowledge in professional practice. This gap awaits further investigation and was not directly the subject of the study. Third, there is a possible bias in the data in terms of the new teachers having exaggerated opinions of their effectiveness as professionals. Finally, attrition may have biased the data toward positive assessments: there was a time lapse of almost nine years since the first graduating cohort and the time of the present study. A substantial number had either moved from the area or changed schools.

Evidence from this study supports the conclusion that exposure to research findings plays an essential and vitally important role in the formation of the teachers (see also Cross, 1991; Ravid, 1997). Teachers benefited from entering and being part of a community of colleagues with a common base of knowledge and understanding. These data also suggest that teachers and specialists in education encountered many challenges in working with ELL children and were often frustrated by having to work around policies that disregarded intake variation among schools.

These findings speak to the continued problems of language minority students and their families, particularly the lack of voice and empowerment in the schools 
amid a backlash of subtle hostility and blame caused by low achievement scores on standardized tests. The ability of the graduates to ask difficult questions and articulate their concerns in terms of evidence rather than anecdotes was empowering and helped them to speak up for what they believed was right.

\section{Notes}

1. In-service training consists of district or site-based workshops on topics aligned to the Sunshine State mandates for ESOL compliance. Three hundred in-service points (equaling 15 graduate credit hours) are required for ESOL endorsement. Fifty points or six credit hours are required for re-certification.

\section{Acknowledgements}

We are grateful to the graduates of the master's program who shared their stories with us. The input of Marta Cruz Janzen and Dilys Schoorman was critical in the development and piloting of the questionnaire. Special thanks are given to Subi Subhan, the research assistant who worked on the project. Funding was generously provided by the Canada-US Fulbright Commission.

Judith K. Bernhard, a Professor at Ryerson University in Toronto Canada, was a Fulbright Scholar at Florida Atlantic University. Her research has focused on the needs of children and families in early education settings. Much of Dr Bernhard's work has addressed the development and education of bilingual groups.

Carlos F. Diaz is a professor of multicultural education at Florida Atlantic University, where he has taught since 1988 . He is editor and contributing author of Multicultural Education for the 21st Century, coauthor of Global Perspectives for Educators and coauthor of Touch the Future: Teach.

Ilene Allgood is an adjunct professor in the College of Education, Department of Teacher Education at Florida Atlantic University in Boca Raton, Florida. As Associate Education Director of the Anti-Defamation League, a US national civil rights agency, she has launched extensive anti-bias programs.

\section{References}

Advocates for Children (2001) Report from the front lines: What's needed to make New York's ESL and bilingual programs succeed (New York, Rockefeller Sterling Clark Foundation).

Ahlquist, R. (2003) Challenges to academic freedom: California teacher educators mobilize to resist state-mandated control of the curriculum, Teacher Education Quarterly, 30(1), 57-64.

Berlak, A. (2003) Who's in charge here?: teacher education and 2042, Teacher Education Quarterly, 30(1), 31-40.

Bernhard, J. K., Winsler, A. \& Bleiker, C. (2004) The Early Authors Program: a Miami-Dade early literacy initiative. Unpublished report (Florida, Miami-Dade School Readiness Coalition).

Bransford, J. D., Brown, A. L. \& Cocking, R. R. (Eds) (1999) How people learn: brain, mind, experience, and school (Washington, DC, National Academies Press). 
Chang, C. N., Chen S. M., Lee, Y. A., Yoneda, F. \& Johnson, M. (2003) The Med/PDS program at the Ohio State University: how does the program prepare culturally responsive teachers? paper presented at the Annual Conference of the American Educational Researchers Association, Chicago, IL.

Cross, C. T. (1991) Education, research and development for teacher learning: leadership roles. Paper presented at the invited address at the annual meeting of American Association of Colleges for Teacher Education, Atlanta, GA.

Cummins, J. (2002) Beyond instructional techniques and standardized assessment: implementing classroom interactions that foster power, identity, imagination and intellect among culturally diverse students, Contact, 28(2), 21-31.

Cummins, J. \& Fillmore, L. W. (2000) Language and education: what every teacher (and administrator) needs to know (Cassette Recording No. NABE00-FS10A) (Dallas, TX, CopyCats.)

Davies, P. (1999) What is evidence-based education? British fournal of Educational Studies, 47(2), $108-121$.

Davies, S. \& Guppy, N. (1997) Globalization and educational reforms in Anglo-American democracies, Comparative Education Review, 41(4), 435-460.

Donovan, S. C. C. (2002) Minority students in special and gifted education (Washington, DC, National Academy Press).

Evans, J. \& Benefield, P. (2001) Systematic reviews of educational research: does the medical model fit? British Educational Research fournal, 27(5), 527-541.

Feuer, M. J., Towne, L. \& Shavelson, R. J. (2002). Scientific culture and educational research, Educational Researcher, 31(8), 4-14.

Gibson, R. (2003) Can communities of resistance and transformation be born from the social context of school? Teacher Education Quarterly, 30(1), 41-55.

González, J. M. \& Darling-Hammond, L. (1997) New concepts for new challenges: professional development for teachers of immigrant youth (McHenry, IL, Delta Systems).

Hemsley-Brown, J. \& Sharp, C. (2003) The use of research to improve professional practice: a systematic review of the literature, Oxford Review of Education, 29(4), 449-471.

Hermans, P. (2002) Intercultural education in two teacher-training courses in the North of the Netherlands, Intercultural Education, 13(2), 183-199.

Hoffman, L. (2003) The common core of data: overview of public elementary and secondary schools and districts: school year 2000-01. Last accessed April 4, 2004, from http:// nces.ed.gov/pubs2003/overview03

Horn, R. A. J. (2004) The new Federal definition of educational research: implications for educators, The Teacher Educator, 39(3), 196-211.

Lahdenpera, P. (2000) From monocultural to intercultural educational research, Intercultural Education, 11(2), 201-207.

Nieto, S. (2003) Profoundly multicultural questions, Educational Leadership, 60(4), 6-10.

Polakow-Suransky, S. (2002) America's least wanted: zero-tolerance policies and the fate of expelled students, in V. Polakow (Ed.) The public assault on America's children: poverty, violence, and juvenile injustice (New York, Teacher's College Press), 101-129.

Ravid, R. (1997) The research component in graduate teacher education programs: asking the stakeholders, paper presented at the Annual Meeting of the Midwestern Educational Research Association, Chicago, IL. October.

Secada, W., Chavez-Chavez, R., Garcia, E., Munoz, C., Oakes, J., Santiago-Santiago, I. \& Slavin, R. (1998) No more excuses. Final report of the Hispanic Dropout Project (Washington, DC, US Department of Education).

Stoer, S. R. \& Cortesao, L. (2001) Action-research and the production of knowledge in a teacher education based on inter/multicultural education, Intercultural Education, 12(1), 65-78.

Tellez, K. (2003) Three themes on standards in teacher education: legislative expediency, the role of external review, and test bias in the assessment of pedagogical knowledge, Teacher Education Quarterly, 30(1), 9-18. 
US Department of Education (2001) Public Law PL 107-110, No Child Left Behind Act of 2001. Available online at: http://www.ed.gov (accessed 28 July 2005).

Weiner, G. (2002) Uniquely similar or similarly unique? Education and development of teachers in Europe, Teaching Education, 13(3), 273-288.

Wenger, E. (1998) Communities of practice: learning, meaning, and identity (New York, Cambridge University Press).

\section{Appendix 1: Demographics of survey respondents}

Out of the 57 survey respondents, $47(82 \%)$ were female and $10(18 \%)$ male. Sixty per cent of the respondents had been in the teaching profession between six and 15 years, and 35\% for more than 15 years. Only one had been teaching for less than five years (see Table A1).

Table A1. Teaching experience in years

Years teaching

5 years or less

6-15 years

16 years or more

Total
Per cent $(N)$

$38(20)$

$100(52)$

Half of the respondents were mainstream classroom teachers, while $30 \%$ reported being designated ESL teachers (see Table A2). Only 7\% were teaching in classrooms for children designated as having special needs. The participants were equally divided between teaching in elementary and secondary schools.

Table A2. Grades in which respondents were currently teaching

\begin{tabular}{lr}
\hline Grade level & Per cent $(N)$ \\
\hline $1-5$ & $29(16)$ \\
$6-8$ & $5(3)$ \\
$9-12$ & $29(16)$ \\
Administration & $29(16)$ \\
Pre-K-5 & $2(1)$ \\
$6-12$ & $2(1)$ \\
High school and college & $2(1)$ \\
Pre-K-12 & $2(1)$ \\
Total & $100(55)$
\end{tabular}


While the majority of the respondents remained in classroom level positions (66.7\%), almost one-third (29.8\%) had been promoted to administrative positions since graduating from the master's program. In addition to completing the master's program, 50 of the respondents $(95 \%)$ had participated in staff development or inservice training provided by the local school boards.

The survey asked about ethnic background and the use of languages other than English in their classrooms. While $40.4 \%$ of the respondents reported speaking a language other than English, only $18 \%$ used this language in the classroom. Other languages spoken by participants were Spanish (11), French (4), Hebrew (2), Creole (1), and Finnish (1). The majority of the respondents (71.9\%) identified themselves as having a European-American heritage. 